\title{
Progesterone Receptor Isoform A
}

National Cancer Institute

\section{Source}

National Cancer Institute. Progesterone Receptor Isoform A. NCI Thesaurus. Code

C128315.

Progesterone receptor isoform A (769 aa, $\sim 82 \mathrm{kDa}$ ) is encoded by the human PGR gene.

This protein plays a role in the regulation of gene transcription. 